\title{
INTELLIGIBILITY OF ENGLISH REGULAR VERBS IN THE PAST TENSE: A STUDY WITH BRAZILIAN LISTENERS AND SPEAKERS OF DIFFERENT L1S
}

\author{
Inteligibilidade de verbos regulares do inglês no passado simples: um \\ estudo com ouvintes brasileiros e falantes de diferentes L1s
}

Fernanda DELATORRE

Universidade Federal de Santa Catarina

nandadela@uol.com.br

https://orcid.org/0000-0001-9458-7778

Rosane SILVEIRA

Universidade Federal de Santa Catarina

Conselho Nacional de Pesquisa e Desenvolvimento Científico e Tecnológico rosanesilveira@hotmail.com https://orcid.org/0000-0003-0329-0376

\begin{abstract}
This study investigated the intelligibility of regular verbs in the past produced by eight speakers of English whose first language (L1) were English, German, Spanish, or Brazilian Portuguese. Fourteen Brazilian learners of English participated as listeners and orthographically transcribed sentences produced by the speakers in two intelligibility tests. Acoustic analysis of the productions revealed that some verbs were produced in a non-target like form, but all productions were kept in the intelligibility tests in order to reflect the variability of input received by Brazilian learners of English. The orthographic transcriptions were analyzed and classified as intelligible (when transcriptions matched the form produced by the speaker), other verb forms (when transcriptions matched the verb produced, but in a different tense or form), and breakdowns in communication (when transcriptions mismatched the target verb or when the verb or the entire sentence was not transcribed). Results reveal that the number of intelligible verbs increased from the first to the second intelligibility test. The number of other verb forms decreased, and the number of breakdowns remained quite similar across the two tests. Results also indicate that speakers' L1, listeners' lack of familiarity with speakers' accent and English pronunciation, as well as test conditions possibly influenced the intelligibility of verbs ending in -ed by Brazilian listeners. KEYWORDS: Speech intelligibility; -ed morphemes; English
\end{abstract}

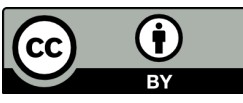


pronunciation; Brazilian listeners.

RESUMO: O presente estudo investigou a inteligibilidade de verbos regulares no passado produzidos por oito falantes do inglês, cuja língua materna (L1) era inglês, alemão, espanhol ou português brasileiro. Quatorze brasileiros participaram como ouvintes e transcreveram ortograficamente as sentenças produzidas pelos falantes em dois testes de inteligibilidade. A análise acústica das produções revelou outros tipos de pronúncia diferentes das formas-alvo, mas todas as produções foram mantidas nos testes de inteligibilidade a fim de refletir a variabilidade do insumo linguístico. As transcrições ortográficas foram analisadas e classificadas como inteligíveis (quando as transcrições corresponderam à forma produzida pelo falante), outras formas verbais (quando as transcrições corresponderam ao verbo produzido, mas em um tempo ou forma diferente) e falhas na comunicação (quando as transcrições não corresponderam ao verbo alvo ou quando não houve a transcrição do verbo ou a sentença completa não foi transcrita). Os resultados revelam que o número de verbos inteligíveis aumentou do primeiro para o segundo teste de inteligibilidade. O número de outras formas verbais diminuiu e o número de falhas na comunicação permaneceu semelhante nos dois testes. Os resultados indicam que a L1 dos participantes, a falta de familiaridade dos ouvintes com o sotaque dos falantes e sua pronúncia do inglês, bem como as condições de teste possivelmente influenciaram a inteligibilidade dos verbos terminados em -ed. PALAVRAS-CHAVE: Inteligibilidade da fala; Morfema -ed; Pronúncia do Inglês; Ouvintes Brasileiros.

\section{INTRODUCTION}

Many studies have focused on phonological prediction error and analysis of first language (L1) interference, comparison between native and non-native speakers' production, second language (L2) speech perception and production, and learner variables (e.g., age of learning, length of residence), which could account for individual differences in the learning process. However, Munro and Derwing (2015) propose that studies on L2 pronunciation may go further and focus on L2 learners' intelligibility (i.e., how much an utterance is actually understood), for instance. Silveira et al (2017) revealed that most studies conducted in Brazil have focused on the perception and production of single segments in cross-sectional studies, and few of them had investigated suprasegmental features or the intelligibility of English sounds.

The phonological phenomenon investigated in this paper is the different pronunciations of the English -ed morpheme when it is used to form the past tense 
form of regular verbs. Pronunciation textbooks (e.g., CELCE-MURCIA; BRINTON; GOODWIN, 2010) and introductory manuals of English phonetics and phonology (e.g., YAVAS, 2011) describe three types of pronunciation for the -ed morpheme: [Id], [d], and $[\mathrm{t}]$. The [Id] pronunciation is expected when the base form of the verb ends in an alveolar stop (e.g., 'voted', 'added'), while [d] is expected when the verb ends in a vowel or a voiced consonant (e.g., 'tried', 'called'), and [t] should occur when the verb ends in a voiceless consonant (e.g., 'worked', 'wiped'). Although the -ed pronunciation is neatly presented in textbooks that tend to describe the language based on the standard varieties of English, our experience with English as a tool for communication among speakers from different L1 backgrounds (CRYSTAL, 2003) makes us question whether these three types of pronunciation cover all possible productions of the -ed morpheme input that language learners are exposed to. We hold the view that L2 development is much more complex, especially when we talk about English, a language that is widely used for international communication. Thus, when focusing on intelligibility, we should investigate how listeners interact with input that goes beyond the standard forms of the language that they are learning.

Regarding the linguistic form investigated in the present study (i.e., verbs ending in -ed), previous studies with Brazilian Portuguese (BP) and/or Spanish L1 speakers learning English revealed that learners tend to add an epenthetic vowel when pronouncing regular verbs in the past tense (e.g., ALVES, 2004; CABELLERO; ROSADO, 2018; DAVILA, 2018; DELATORRE, 2006, 2010; DELATORRE; BAPTISTA, 2014; FERNANDES, 2009; FRESE, 2006; GOMES, 2009; MARIANO, 2009; PEREIRA, 1994; SILVEIRA; ALVES, 2009). Furthermore, studies with Brazilians have investigated (a) the relationship between verb perception and production (e.g., FRESE, 2006, SILVEIRA; ALVES, 2009); (b) verb perception only (e.g., ROSSINO; FRACARO; BRAWERMAN-ALBINI, 2019; ROSSINI et al., 2018), (c) the effects of instruction or perceptual training in verb production (e.g., ALVES, 2004; DELATORRE; BAPTISTA, 2014; MARIANO, 2009; SILVEIRA; ALVES, 2009), and, (d) verb intelligibility (e.g., DELATORRE; SILVEIRA; GONÇALVES, 2017; FERNANDES, 2009; GOMES; BRAWERMAN-ALBINI; ENGELBERT, 2014; RIELLA, 2013).

It is a fact that communication and interaction among English speakers, either native or non-native, have increased (BABBONI; QUAST, 2020; CRYSTAL, 2003; KACHRU, 1985; ROSA, 2020; ROXAS, 2018; SMITH; NELSON, 1985). Thus, considering the growing interest on intelligibility studies and the fact that the production of regular verbs ending in -ed by Brazilians tends to deviate from the target-like patterns 
(DELATORRE; SILVEIRA; GONÇALVES, 2017), the present study investigates the intelligibility of verbs ending in -ed when these verbs are produced by speakers from different L1 backgrounds, including native and non-native speakers of English.

In addition to this introductory section, the present article brings a brief review of literature addressing intelligibility and L2 pronunciation assessment. The method section presents the study design, its participants, research instruments and procedures for data collection and analysis. The results are then presented and discussed in order to answer the two research questions guiding the study. The article ends with a brief concluding section.

\section{LITERATURE REVIEW}

In this section, we address key terms in the field of L2 speech assessment, a brief review of relevant intelligibility studies to highlight relevant factors for the present research, as well as a review of intelligibility research involving Brazilian learners of English and the pronunciation of the -ed morpheme.

\section{Intelligibility, speech characteristics, accent and pronunciation}

Catford (1950) considers that an utterance may be effective and intelligible when it establishes communication between the hearer and the speaker and induces the speaker to make the correct or more adequate linguistic choices. Catford acknowledges that an utterance may be intelligible but ineffective if the hearer's response is not what the speaker was expecting to get.

Smith and Nelson (1985, p. 334) present the concepts of intelligibility, comprehensibility and interpretability. They define intelligibility as "words/utterance recognition", comprehensibility as "word/utterance meaning", and interpretability as "meaning behind word/utterance".

However, Munro and Derwing (1995) put forward a different concept of intelligibility, one that encompasses all the definitions made by Smith and Nelson (1985) since it involves "shared knowledge and social context" (MUNRO; DERWING, 2015, p. 379), which may affect understanding. Therefore, Munro and Derwing (1995) define intelligibility as the extent to which an utterance is understood, which may be assessed by the orthographic transcription of the utterance. Munro and Dewing (1995) also define additional dimensions of L2 speech; namely, comprehensibility and accentedness. Comprehensibility is defined as the perceived difficulty in understanding an utterance, and accentedness as how much a speaker's foreign accent is perceived to differ from 
the variety "commonly spoken in the community" (MUNRO, DERWING, 1995, p. 385). Both comprehensibility and accentedness are commonly assessed with the help of rating scales. Munro and Derwing's (1995) definition of intelligibility is adopted in the present study.

Munro and Derwing (2015) highlight that listeners may partially or fully understand utterances they hear or even misjudge the unintelligible ones by believing they understood them, when, in fact, they did not. Furthermore, Bradlow and Pisoni (1999) and Munro, Derwing and Morton (2006) advocate that some variables, such as phonological properties of speakers' output, listeners familiarity with accents, listeners' and speakers' L1s, may interfere with intelligibility.

Alameen and Levis (2015), Derwing and Munro (2015), Levis (2015) and Munro and Derwing (2015) also explain that listeners may be aware of differences in speakers' speech, accent and pronunciation, but that these factors may or may not interfere in communication and/or in listeners' judgments and understandings of L2 pronunciation and speech. Munro and Derwing (1995) point out that for both, listener and speaker, foreign accent may cause misunderstandings since it makes the recognition of segments, words, and larger structures more difficult, even when they are understood. Moreover, misunderstandings may irritate the listener because accented messages require more processing time as they are not similar to the prototypes in the listener's memory.

Furthermore, Munro and Derwing (2015) consider that, in real communication, the production of words is always influenced by words that occur close to them, the situation in which they are produced (e.g., connected/free speech or sentence/paragraph reading), as well as the social context and physical environment (e.g., quiet or noisy environment). These factors may interfere with listeners' understanding of messages, as observed by Alameen and Levis (2015), Babboni and Quast (2020), Munro and Derwing (2015), and Trofimovich, Kennedy and Foote (2015).

It is noteworthy that, as supported by Smith and Nelson (1985), the native speaker is not the only judge of what is intelligible in English since non-native speakers are interacting in English. In addition, the authors claim that intelligibility is the focus in the interaction between speaker and listener, and that the greater the involvement and familiarity a learner has with an individual speaker or English variety, the more intelligible the speaker's speech and that specific variety of English will be for this learner.

In the following section, the role of speakers' and listeners' L1 background will be examined by reviewing studies that looked into how speech intelligibility is influenced 
by factors such as L1 similarity, accent familiarity, speech rate, L2 proficiency and vocabulary knowledge.

\section{Studies with speakers of English from different L1 backgrounds}

Munro, Derwing and Morton (2006) investigated the intelligibility, comprehensibility and accentedness of 48 L1 speakers of Japanese, Cantonese, Polish, and Spanish (12 from each L1) as rated by 40 listeners (including 10 Japanese and 10 Cantonese participants who shared the L1 with talkers, 10 speakers of Mandarin who did not speak either Japanese or Cantonese, and 10 English L1 speakers). The authors found weak evidence that sharing the L1 and accent familiarity lead to better understanding since they only observed a slight advantage for Japanese listeners rating Japaneseaccented English, which was possibly influenced by Japanese listeners' use of English, given that they reported more frequent daily use of English than Cantonese and Mandarin L1 listeners. As there was only a slight difference in the analysis of Japanese speakers by Japanese listeners, the authors concluded that both native and non-native listeners rated foreign-accented English in the same way despite their different L1s.

Bradlow and Pisoni (1999) investigated English native and non-native speakers' recognition of easy and hard ${ }^{1}$ words produced by ten native speakers of American English. Two groups of listeners, one of 20 native speakers of American English and a second one of 20 non-native speakers of English (Korean, Chinese, Russian, Japanese, Spanish, Bengali, Nepali, and Dani L1 speakers) identified the words recorded by the speakers in three different speaking rates. Bradlow and Pisoni (1999) found that listeners easily identified words produced by the same speaker and more often correctly identified easy words than hard words at the medium speaking rate, indicating that the listeners got more used to the same speaker's voice and articulation, which facilitated the identification of words produced by the same speaker. The authors observed that signal characteristics, such as speaking rate, listeners' knowledge about language sounds, their experience with speakers' voice, and sound articulation determined listeners' performance on the intelligibility test.

Bent and Bradlow (2003) investigated the intelligibility, comprehensibility, and the role played by listeners' familiarity with English words. Five female speakers (one native speaker of English, two native speakers of Chinese and two native speakers of

\footnotetext{
${ }^{1}$ According to Bradlow and Pisoni (1999), easy words are words that have few phonetic similar words, while hard words have many phonetic similar words. For this reason, listeners tend to have more difficulty with hard words than with easy words.
} 
Korean) participated in the study. Among the non-native speakers, one Chinese and one Korean L1 speaker were considered highly proficient in English, and the other Chinese and Korean speakers had low proficiency in English. Sixty-four listeners were divided in four groups; one group with 21 Chinese L1 listeners, a second one with 10 Korean L1 listeners, a third one with 12 speakers of different L1s, and the fourth group with 21 native speakers of English. Bent and Bradlow found that most of the words tested in the familiarity test were considered familiar to the listeners. Additionally, they found that low-proficient Chinese and Korean speakers were the least intelligible ones, whereas the native English and the high-proficient Chinese and Korean speakers were the most intelligible ones for listeners with the same L1 backgrounds; that is, to Chinese and Korean L1 listeners. High-proficient Chinese and Korean speakers were more intelligible to seven out of the twelve non-native speakers of English in the mixed L1 group, and that one low-proficient Korean was as intelligible as native speakers. Altogether, the results suggest that there was a matched interlanguage speech intelligibility benefit (i.e., listeners benefited from sharing the L1 with the speaker), and a benefit from speakers' proficiency, in which high proficient non-native speakers of English were more intelligible than the low-proficient speakers.

Jułkowska and Cebrian (2015) investigated the intelligibility, comprehensibility and accentedness of English sentences produced by 11 Polish L1 speakers learning English and two native speakers of British English, and the influence of word-stress and segmental errors on the intelligibility of these sentence. Six Polish (matched-L1), six Spanish listeners learners of English (mismatched-L1), and six native speakers of English participated as listeners. The speakers recorded 39 sentences which were then randomly presented to the 18 listeners who heard them once, orthographically transcribed them, and rated them for accentedness and comprehensibility using 9-point Likert scales. Results of Jułkowska and Cebrian's (2015) study demonstrated that the relationship between intelligibility and comprehensibility was strong, and that the relationship between intelligibility and accentedness was weak, thus corroborating previous studies. In addition, all listeners (Spanish, Polish, and English L1 speakers) considered English speakers more intelligible and comprehensible than speakers of Polish. English and Spanish listeners considered English speakers more intelligible than Polish speakers, and only Polish listeners considered Polish speakers as intelligible as native English speakers. The authors concluded that familiarity with Polish accented English possibly facilitated the recognition of Polish speakers' speech by Polish listeners, whereas lack of familiarity with it possibly affected Spanish listeners' recognition of Polish speakers' speech. 
Becker (2013) aimed to investigate the intelligibility of English sentences produced by speakers of four L1s and transcribed by Brazilian learners. She asked 80 Brazilian learners of English to listen to a paragraph recorded by eight speakers of English, one male and one female native speaker of Mandarin, Japanese, German and American English. Four groups of 20 Brazilian listeners analyzed the recordings of two speakers from the same L1, in which 10 listeners of each group listened to the male and 10 listeners listened to the female speaker. Listeners were asked to indicate, in percent, how much they understood from that reading passage; then, they listened to the text divided into small parts and wrote down what they could understand; finally, they listened to the whole text again and indicated tokens that were the most difficult to understand. They were also asked to guess the nationality of the speaker. Becker's (2013) results indicate that $77.2 \%$ of all words produced by Germans, $77 \%$ of all words produced by Americans, $80.1 \%$ of all words produced by Mandarin speakers and $61.3 \%$ of the words produced by Japanese speakers were intelligible to the 20 Brazilians who listened to each group of speakers. By comparing the groups of speakers, the results suggest that English spoken by Japanese talkers was not so intelligible to Brazilian listeners as English spoken by Mandarin, German and English speakers seemed to be. In other words, Brazilians had more difficulty in understanding English spoken by Japanese speakers than by Mandarin, German, and English speakers.

Roxas (2018) investigated the intelligibility and comprehensibility of English by the members of the Association of Southeast Asian Nations (ASEAN) who use English as their official language to communicate and interact among themselves, with Great Britain, and with the United States (i.e., users of English as a Lingua Franca). Members of ASEAN are speakers of Philippine English, Brunei English, Singapore English, and Malaysian English. One university student speaker of Philippine English, Singapore English, and Malaysian English participated in this study as speakers ${ }^{2}$ and 47 Filipino university students participated as listeners. Each speaker recorded a script that was presented twice to the listeners who had to listen to it once, fill in the blanks with the missing content words (intelligibility test), and answer five questions while listening to each script for the second time (comprehensibility test). They listened to the Singapore English speaker first, followed by the Malaysian English speaker, and, finally, by the Philippine English speaker. Roxas (2018) found that speakers of ASEAN English were highly intelligible to the Filipino listeners since their pronunciation seems to follow the

\footnotetext{
${ }^{2}$ The author explained that it was not possible to find an educated speaker of Brunei English to participate in the study (ROXAS, 2018, p. 2).
} 
same rhythmic pattern. Furthermore, speakers' utterances had few pronunciation features that seemed to have had little interference on the listeners' ratings. In addition, the Singapore English speaker was the most intelligible speaker, followed by the Philippine English speaker, and, then, by the Malaysian English speaker. This finding suggests that sharing the L1 is not the most important element to mutual intelligibility. Regarding comprehensibility, the author found high comprehensibility of Philippine, Singapore and Malaysian Englishes for Filipino listeners, which the author attributes to the similarity between the speakers' L1, besides geographic proximity among the countries they come from. The fact that English is considered essential for interaction within the ASEAN countries and for their integration with other countries in Asia, Europe, or the Americas was also interpreted as reason for high comprehensibility levels.

Kennedy and Trofimovich (2008) conducted a study examining the role of the listener in intelligibility, comprehensibility and accentedness ratings of English produced by six Mandarin L1 speakers learning English in Canada and six native English speakers. The speakers produced 90 utterances that were rated by 24 adult native English-speaking listeners, 12 who had experience with foreign accented English and 12 without this type of experience. Results obtained by Kennedy and Trofimovich (2008) indicate that experienced listeners understood more from both native and non-native English speakers than inexperienced listeners, who only understood better the native English speech. Experienced and inexperienced listeners rated Mandarin and English speakers' speech in the same way regarding comprehensibility and accentedness.

The studies reviewed in this section demonstrate the complexity of L2 speech intelligibility. They also raise researchers' awareness to possible factors that need to be considered in this type of research, including familiarity with speakers' L1, L2 accent, the topic of the stimuli, as well as the proficiency level of speakers and listeners. In the next section, we turn our attention to studies that investigated the intelligibility of verbs with the -ed endings produced and/or assessed by Brazilians.

\section{Studies on the intelligibility of -ed endings with Brazilian speakers and listeners}

Fernandes (2009) investigated the intelligibility of English verbs ending in -ed produced by five Brazilian learners as rated by five European Portuguese (EP) and five Hindi L1 listeners. Fernandes recorded Brazilians describing a picture and reading short texts with -ed instances. EP and Hindi listeners rated the story telling task in a three-point Likert scale and orthographically transcribed the texts read by one Brazilian informant. Fernandes' (2009) results show that BP speakers' speech was rated as 
moderately comprehensible by both groups of listeners, and that EP listeners displayed higher intelligibility rates (around 70\%) than Hindi listeners (around 40\%). Both groups of listeners indicated that vowel epenthesis, rhythm and intonation affected their intelligibility rating in the story telling task.

Riella (2013) examined the intelligibility of English verbs ending in -ed produced by 46 Brazilians and two native speakers of English, focusing on epenthesized productions and whether they affected the intelligibility. Thirty listeners were assigned to three groups. Group 1 had ten native speakers of English, group 2 had ten Brazilians speakers of English, group 3 had ten English speakers from different L1s. Recordings of text reading and spontaneous speech were presented to the listeners. First, participants orthographically transcribed the sentences they had listened to twice. Then, they were asked to rate ten sentences recorded by Brazilians in a previous study (GOMES, 2009). Orthographic transcriptions of these additional sentences were also presented to the listeners, who rated the sentences using a five-point Likert scale. Riella's (2013) results for group 1 and group 2 were the same, and revealed 71\% of correct transcription of verbs ending in -ed. According to Riella, this rate of correct transcriptions occurred even when there was vowel epenthesis in verb pronunciation. Results of group 3 were less homogeneous when compared to the other groups, as group 3's overall intelligibility rate dropped to $60 \%$, and its overall blank answer percent was higher (24\%), suggesting breakdown in communication. In addition, Riella's results for group 1 possibly indicate lack of intelligibility and breakdown in communication due to vowel epenthesis, and both native and non-native speakers' accent familiarity. Brazilian listeners (group 2) easily understood other Brazilians' speech. As listeners in Riella's study understood Brazilians' speech despite vowel epenthesis production and accent, Gomes, Brawerman-Albini and Engelbert (2014), who analyzed Riella's data, observed that vowel epenthesis was not problematic for the three groups of listeners since it causes fewer intelligibility problems than consonant deletion.

Delatorre, Silveira and Gonçalves $(2017)^{3}$ investigated the intelligibility of English verbs ending in -ed. Thirty-two sentences containing 24 regular and eight irregular verbs in the simple past were audio-recorded by eight speakers ${ }^{4}$ of English from different L1 backgrounds (BP, Spanish, German, English). Each speaker read and audiorecorded the 32 sentences each containing either one irregular verb in the past or one

\footnotetext{
${ }^{3}$ This was a pilot study conducted to calibrate the research instruments and procedures of the present study.

${ }^{4}$ Speakers and sentences are the same of Delatorre's (2017) study.

Revista X, v. 16, n. 5, p. 1293-1323, 2021. 
regular verb with one of the three possible -ed pronunciations ${ }^{5}$. Four sentences from each speaker were used to create the intelligibility test, which were completed by 13 Brazilian listeners. Participants listened twice to the 32 sentences and orthographically transcribed them. The transcriptions were analyzed and classified as: (a) intelligible, when it was transcribed exactly as it was produced by the speaker; (b) other verb form, when it was transcribed in stem form, third person singular or ing form; and, (c) as causing breakdown in communication, when the verb was not transcribed, replaced by another word or when it or the entire sentence was not transcribed at all.

Results indicate that the breakdown in communication rate was higher than the intelligibility rate, which was higher than the rate for other forms for all verbs combined as well as for regular and irregular verbs individually. Delatorre, Silveira and Gonçalves (2017) found a tendency for BP and Spanish speakers' productions to be more intelligible than German and English speakers' productions, which did not reach statistical significance. Both regular and irregular verbs produced in a target-like fashion by speakers from all four L1s had low intelligibility rates, which was attributed to subtle changes in the coda or overall accent that may affect intelligibility, as suggested by Bradlow and Pisoni (1999) and Munro and Derwing (1995).

The studies reviewed in this section support the use of English as a lingua franca (SEIDLHOFER, 2011) and show that the focus on intelligibility in L2 speech research has increased. Nonetheless, the intelligibility of L2 learners' speech production has frequently been assessed by English native speakers, and research considering how Brazilian learners of English rate speech produced by speakers from different L1 backgrounds is still scarce. The present study intends to investigate Brazilians' intelligibility of verbs ending in -ed, measured through a transcription task, produced by speakers of four different languages. Two intelligibility tests were administered to Brazilian listeners.

\section{METHOD}

This section presents information about the study; namely, about participants, research instruments, data collection and analysis. The data were collected with a fourmonth interval between the two data collection sessions with the objective of examining whether further experience with classroom-based learning influenced listeners' responses.

\footnotetext{
${ }^{5}$ See the sentences in Appendix A. 


\section{Participants}

Two groups of participants collaborated with the study: Eight speakers and fourteen listeners. The speech samples were recorded by two native speakers of BP, Spanish, German, and English, being one male and one female from each language. Speakers' age varied from 20 to 55 years old. They were living in Brazil during data collection. The length of study for non-native speakers of English varied as follows: 4 years (GT2), 7 years (ST2), 11 years (BPT1), 13 years (GT1), 16 years (BPT2), and 23 years $(\mathrm{ST} 1)^{6}$. They all reported using English for work and/or study purposes.

Listeners were 14 Brazilian leaners of English; 12 females and two males. They were all undergraduate students in Executive Secretary at a Brazilian university (age: from 18 to 46 years old). Participants were enrolled in the $2^{\text {nd }}$ and $4^{\text {th }}$ semesters when the first intelligibility test was administered, and in the $3^{\text {rd }}$ and $5^{\text {th }}$ semester, respectively, when the second intelligibility test was administered. Listeners' English proficiency level was estimated with a paper and pencil version of the Oxford Placement Test (ALLAN, 2004). The results of this test showed that their proficiency ranged from beginner (16 points in the $\mathrm{CEFR}^{7}$ ) to Upper-Intermediate (44 points in CEFR) ${ }^{8}$. As part of their undergraduate program curriculum, they had 100-minute English classes four times a week.

\section{Data collection and analysis}

Speakers were recorded individually reading a list of 96 short sentences ${ }^{9}$ containing subject, a regular or an irregular verb (the latter worked as distractor in the study), in the past, followed by a complement without any past marker, such as 'yesterday' or 'last year.' The recordings were made in a sound-attenuated room as the recordings were acoustically analyzed ${ }^{10}$. Speakers answered a background questionnaire ${ }^{11}$ after the recording session.

\footnotetext{
${ }^{6} \mathrm{BPT}=$ Brazilian Portuguese talker; $\mathrm{ST}=$ Spanish talker; GT $=$ German talker; ET $=$ English talker; $1=$ female talker and $2=$ male talker

${ }^{7}$ CEFR stands for Common European Framework of Reference. The OPT test allows placing the participants using the CEFR overall proficiency scales.

81 Beginner (A1, 10-17 points); 5 Elementary (A2, 18-29 points); 5 Lower Intermediate (B1, 3039 points) and 3 Upper Intermediate (B2, 40-47 points) in CEFR.

${ }^{9}$ See Appendices D and G in Delatorre (2017) for the 96 sentences.

10 The pronunciation of all verbs is analyzed and discussed in Delatorre, Gonçalves and Silveira (2020).

${ }^{11}$ Questionnaires that speakers and listeners answered are available in Delatorre (2017).

Revista X, v. 16, n. 5, p. 1293-1323, 2021. 
Four sentences recorded by each speaker with one irregular verb or one regular verb with one of the three -ed pronunciations were selected. The first 32 sentences were used in the first intelligibility test, and the other 32 sentences $^{12}$ were used in the second intelligibility test. Informants listened to each sentence twice and orthographically transcribed them, after having read and signed a consent form, as well as answered a background questionnaire. The first and second intelligibility tests were administered within a four-month interval.

After the second test, participants' orthographic transcriptions of the 64 verbs were analyzed and labeled as: (a) intelligible, when verbs were transcribed as they were produced; (b) other forms, when verbs were transcribed differently from the form they were produced (i.e., in the stem form, in the third person singular when they were produced in the present, or in the -ing form); or (c) causing breakdowns, when verbs were replaced by another word, not transcribed, or when the entire sentence was not transcribed. As this study focuses on the intelligibility of verbs ending in -ed, the intelligibility of irregular verbs is not considered. Thus, only 48 verbs, 24 in each intelligibility test, including one verb for each of the three -ed pronunciations produced by each of the eight speakers, were evaluated according to listeners' transcriptions, resulting in 336 verbs analyzed in each test session. The number and percentage of intelligible verbs, other verb forms, and breakdowns in both intelligibility tests were calculated in order to answer the following research questions:

1. How is the English -ed ending produced by speakers from different L1 backgrounds?

2. How intelligible are these productions for Brazilian listeners across time?

In the following section, we present the results and attempt to answer these questions. First, we examine how the speakers produced the -ed endings, then we analyze the transcriptions provided by the listeners.

\section{RESULTS AND DISCUSSION}

This study intended to investigate the production of English regular verbs in the past and their intelligibility to Brazilian learners of English as listeners. Therefore, we analyzed the productions to determine how the -ed endings were actually pronounced

\footnotetext{
${ }^{12}$ See Appendices A and B for the sentences and speakers. 
(target-like, coda change, stem form, epenthesis). Listeners' orthographic transcription were analyzed to examine how intelligible the target verbs were and labeled as: (a) intelligible; (b) other verb forms; and (c) breakdowns in communication.

In order to answer the first research question, we looked into how speakers from different L1 backgrounds produced the verbs ending in -ed. English Pronunciation textbooks explain that the -ed endings should be pronounced as [Id], [d], and [t] according to the preceding phonological context. However, this description assumes that English learners are exposed to input coming from an idealized English native speaker, which is far from the reality of English use nowadays given the fact that English is more frequently spoken by L 2 speakers than by L1 speakers. Thus, in addition to the expected challenges of learning the three possible pronunciations of -ed, English learners are also exposed to other pronunciation possibilities, such as complete deletion of the -ed morpheme, insertion of epenthetic vowels, or even devoicing/voicing of the final alveolar consonant. Therefore, we decided to keep non-canonical productions of the -ed morpheme in the intelligibility tests in order to attain a more realistic picture of how Brazilian learners of English make sense of these productions when they are trying to understand English sentences produced by speakers from different L1 backgrounds.

The characteristics of the -ed productions by the speakers are presented in Table 1 , including the target verbs used in both intelligibility tests and how they were produced (e.g., target-like, coda change, stem form, epenthesis) by each speaker. 
Table 1: Production of the -ed endings according to speaker and verb.

\begin{tabular}{|c|c|c|c|c|c|}
\hline \multicolumn{3}{|c|}{ Verbs used in Intelligibility Test 1} & \multicolumn{3}{|c|}{ Verbs used in Intelligibility Test 2} \\
\hline Speaker & Verb & Production & Speaker & Verb & Production \\
\hline ST2 & Voted & Target-like & GT1 & Proved & Target-like \\
\hline ET2 & Trained & Target-like & ET1 & Attended & Target-like \\
\hline GT2 & Washed & Target-like & BPT2 & Asked & Target-like \\
\hline BPT1 & Cheered & Target-like & ET2 & Danced & Target-like \\
\hline GT1 & Guided & Target-like & ST1 & Crossed & Target-like \\
\hline BPT2 & Played & Target-like & GT1 & Printed & Target-like \\
\hline ET2 & Painted & Target-like & BPT2 & Shared & Target-like \\
\hline GT1 & Laughed & Target-like & ST2 & Adopted & Target-like \\
\hline ST1 & Saved & Target-like & BPT1 & Brushed & Target-like \\
\hline BPT2 & Visited & Target-like & ET2 & Sounded & Target-like \\
\hline ET1 & Judged & Target-like & GT1 & Clapped & Target-like \\
\hline BPT1 & Skipped & Target-like & ST1 & Joined & Target-like \\
\hline ST1 & Avoided & Target-like & ET1 & Failed & Target-like \\
\hline BPT2 & Kissed & Target-like & ST1 & Reminded & Target-like \\
\hline GT2 & Spelled & Target-like & ET1 & Jumped & Target-like \\
\hline ET1 & Recorded & Target-like & ET2 & Called & Target-like \\
\hline GT2 & Waited & Target-like & GT2 & Dressed & Target-like \\
\hline BPT1 & Needed & Coda change & ВРT2 & Counted & Target-like \\
\hline GT1 & Caused & Stem & BPT1 & Rented & Coda change \\
\hline ET2 & Missed & Stem & GT2 & Planned & Coda change \\
\hline ET1 & Stopped & Stem & GT2 & Added & Coda change \\
\hline ST2 & Screamed & Epenthesis & BPT1 & Changed & Stem \\
\hline ST2 & Looked & Epenthesis & ST2 & Tried & Epenthesis \\
\hline ST1 & Watched & Epenthesis & ST2 & Worked & Epenthesis \\
\hline
\end{tabular}

$\mathrm{BPT}=$ Brazilian Portuguese speaker; $\mathrm{ST}=$ Spanish speaker; $\mathrm{GT}=$ German speaker; ET $=$ English speaker; $1=$ female speaker and $2=$ male speaker. 
Table 1 shows that, from the 24 verbs used in the first intelligibility test, 17 were produced in target-like fashion; that is, they contained the expected-ed ending morpheme. Three of them were epenthesized (e.g., 'looked' [lo'ked]), three were produced in the stem form (e.g., 'caused' [koz]), and one of them had a coda change (e.g., 'planted' [plænt]. Similarly, from the 24 verbs used in the second intelligibility test, 18 were target-like produced, three had coda change, two were epenthesized, and one was produced in the stem form. The results also show that epenthetic productions of the -ed ending occurred with two verbs that required the [d] allomorph ('screamed,' 'tried'), and once with a verb that required the [t] allomorph ('looked'). Vowel epenthesis is a type of syllable simplification commonly found in English L2 speech produced by Brazilian and Spanish learners, but, in our dataset, it was present in verbs produced by one Spanish speaker only (ST2). On the other hand, stem form production occurred in tokens produced by the English speakers, one German speaker (GT1), and one Brazilian speaker (BPT1). Stem form productions might result from assimilation of syllable codas. This seems to be the case for the verbs 'caused' and 'missed'; however, the verbs 'stopped' and 'changed' do not offer the phonological context that favors assimilation, so the stem form production with these verbs might have resulted from misreading by both the English and the Brazilian speaker. Finally, coda change was observed in the production of four different verbs: 'needed,' 'rented,' 'planned,' 'added.' These productions appeared in the productions of one Brazilian speaker (BPT1) and one German speaker (GT2). As shown in Table 1, the -ed morpheme was mostly produced in a target-like manner, but there were non-target-like productions as well. Next, we will address the intelligibility of these productions as orthographically transcribed by Brazilian listeners.

The second research question examined the intelligibility of English regular verbs produced by speakers from different L1 backgrounds and transcribed by a group of Brazilian learners of English. Listeners were asked to transcribe sentences containing the target verbs in two different testing sessions that took place with a four-month interval. The reason for administering two tests was to investigate whether further experience with language learning would affect intelligibility scores as the listeners were attending mandatory English classes as part of their undergraduate program. Given the nature of the target forms being analyzed here, we decided to create three categories to classify the transcriptions provided by the listeners: (a) intelligible - when there was a match between the verb produced by the speaker and what the listener transcribed; (b) other form - when the listener transcribed the verb produced by the speaker, but in a different tense or form; and, (c) breakdown - when there was a complete mismatch between the verb produced by the speaker and what the listener transcribed or when it was not transcribed.

The results for the first intelligibility test demonstrated that, among 336 verbs transcribed by Brazilians in the first intelligibility test, 136 (40.4\%) were intelligible, 73 
(21.7\%) were transcribed in other verb forms, and 127 caused breakdowns (37.7\%), as shown in Table 2. For the second intelligibility test, from 336 verbs, 160 (47.6\%) were intelligible, $50(14.8 \%)$ were transcribed in other verb forms, and $126(37.5 \%)$ caused breakdowns. It is evident that the percent of intelligible verbs increased in about seven points across tests, which is mainly because of the lower number of tokens transcribed with other verb forms. However, the percentage of breakdowns, that is, of verbs that were unintelligible, remained very similar across tests.

Table 2: First and second intelligibility test results.

\begin{tabular}{cccc}
\hline Test & Intelligible & Other verb forms & Breakdowns \\
\hline $1^{\text {st }}$ intelligibility test & $136(40.4)$ & $73(21.7 \%)$ & $127(37.7 \%)$ \\
$2^{\text {nd }}$ intelligibility test & $160(47.6 \%)$ & $50(14.8 \%)$ & $126(37.5 \%)$ \\
\hline
\end{tabular}

$$
\mathrm{N}=336 \text { for each test. }
$$

Intelligibility results in both tests were lower than the results of Becker's (2013), Riella's (2013) and Schwartzhaupt's (2015) studies with Brazilian learners of English as listeners. The low percentage obtained for intelligibility in the present study, together with the results for breakdowns in communication, indicate that Brazilians had difficulties in orthographically transcribing the target verb or the sentence in which it was inserted as found by Cruz (2004) and Riella (2013). This finding suggests that the message was probably not so effective and/or intelligible to the Brazilian listeners, as Catford (1950) pointed out.

Tables 3 and 4 present the results of the intelligibility tests in more detail, allowing us to see possible influences of the speaker and the target verb. The tables are split to show the intelligibility rates for the verbs that were produced in a target-like fashion (17 verbs in the first intelligibility test and 18 in the second intelligibility test), and those with other types of productions ( 7 in test 1 and 8 in test 2). As Table 3 shows, in the first test, the intelligibility rate was higher for verbs produced in a non-target-like fashion (46.9\%) than target-like (37.8\%). Similarly, the percentage of transcriptions with other verb forms was higher with non-target like productions. Also surprising was the result that shows that breakdown in communication occurred much more often when the -ed verbs were target-like produced $(43.7 \%)$ than when they were produced with coda change, in the stem form, or with epenthesis (23.4\%). In the second intelligibility test (Table 4), this trend is no longer observed. Possibly due to the listeners' improved familiarity with the test or their extended experience with the English language, their transcriptions reveal higher intelligibility rates for target-like productions $(50.4 \%)$ than for non-target-like productions $(39.2 \%)$. The percentage of other form transcriptions is very similar for the 
different types of production, and breakdown in communication becomes more frequent with non-target like production (45.2\%) than with target-like productions $(34.9 \%)$.

Table 3: Results for the second intelligibility test according to talker and verb.

\begin{tabular}{|c|c|c|c|c|c|}
\hline Speaker & Verb & Production & Intelligibility & Other verb forms & Breakdowns \\
\hline ST2 & Voted & Target-like & $03(21.4 \%)$ & $01(7.1 \%)$ & $10(71.4 \%)$ \\
\hline ET2 & Trained & Target-like & $0(0 \%)$ & $08(57.1 \%)$ & $06(42.8 \%)$ \\
\hline GT2 & Washed & Target-like & $03(21.4 \%)$ & $04(28.5 \%)$ & $07(50 \%)$ \\
\hline BPT1 & Cheered & Target-like & $04(28.5 \%)$ & $0(0 \%)$ & $10(71.4 \%)$ \\
\hline GT1 & Guided & Target-like & $03(21.4 \%)$ & $04(28.5 \%)$ & $07(50 \%)$ \\
\hline ВPT2 & Played & Target-like & $09(64.2 \%)$ & $04(28.5 \%)$ & $01(7.1 \%)$ \\
\hline ET2 & Painted & Target-like & $02(14.2 \%)$ & $0(0 \%)$ & $12(85.7 \%)$ \\
\hline GT1 & Laughed & Target-like & $06(42.8 \%)$ & $02(14.2 \%)$ & $06(42.8 \%)$ \\
\hline ST1 & Saved & Target-like & $03(21.4 \%)$ & $0(0 \%)$ & $11(78.5 \%)$ \\
\hline BPT2 & Visited & Target-like & $14(100 \%)$ & $0(0 \%)$ & $0(0 \%)$ \\
\hline ET1 & Judged & Target-like & $01(7.1 \%)$ & $02(14.2 \%)$ & $11(78.5 \%)$ \\
\hline BPT1 & Skipped & Target-like & $07(50 \%)$ & $05(35.7 \%)$ & $02(14.2 \%)$ \\
\hline ST1 & Avoided & Target-like & $06(42.8 \%)$ & $07(50 \%)$ & $01(7.1 \%)$ \\
\hline ВРТ2 & Kissed & Target-like & $12(85.7 \%)$ & $02(14.2 \%)$ & $0(0 \%)$ \\
\hline GT2 & Spelled & Target-like & $02(14.2 \%)$ & $02(14.2 \%)$ & $10(71.4 \%)$ \\
\hline ET1 & Recorded & Target-like & $04(28.5 \%)$ & $03(21.4 \%)$ & $07(50 \%)$ \\
\hline GT2 & Waited & Target-like & $11(78.5 \%)$ & $0(0 \%)$ & $03(21.4 \%)$ \\
\hline Total & & & $90(37,8 \%)$ & $44(18,4 \%)$ & $10443,7 \%)$ \\
\hline BPT1 & Needed & Coda change & $09(64.2 \%)$ & $04(28.5 \%)$ & $01(7.1 \%)$ \\
\hline GT1 & Caused & Stem & $05(35.7 \%)$ & $03(21.4 \%)$ & $06(42.8 \%)$ \\
\hline ET2 & Missed & Stem & $04(28.5 \%)$ & $06(42.85 \%)$ & $04(28.5 \%)$ \\
\hline ET1 & Stopped & Stem & $04(28.5 \%)$ & $04(28.5 \%)$ & $06(42.8 \%)$ \\
\hline ST2 & Screamed & Epenthesis & $03(21.4 \%)$ & $09(64.2 \%)$ & $02(14.2 \%)$ \\
\hline ST2 & Looked & Epenthesis & $09(64.2 \%)$ & $01(7.1 \%)$ & $04(28.5 \%)$ \\
\hline ST1 & Watched & Epenthesis & $12(85.7 \%)$ & $02(14.2 \%)$ & $0(0 \%)$ \\
\hline Total & & & $46(46.9 \%)$ & $29(29.5 \%)$ & $23(23.4 \%)$ \\
\hline
\end{tabular}

$\mathrm{N}=14$ for each verb and 336 for the total 
Table 4: Results for the second intelligibility test according to talker and verb.

\begin{tabular}{llllll}
\hline Speaker & Verb & Production & Intelligibility & $\begin{array}{l}\text { Other verb } \\
\text { forms }\end{array}$ & Breakdowns \\
\hline GT1 & Proved & Target-like & $03(21.4 \%)$ & $08(57.1 \%)$ & $03(21.4 \%)$ \\
ET1 & Attended & Target-like & $08(57.1 \%)$ & $02(14.2 \%)$ & $04(28.5 \%)$ \\
BPT2 & Asked & Target-like & $12(85.7 \%)$ & $01(7.1 \%)$ & $01(7.1 \%)$ \\
ET2 & Danced & Target-like & $01(7.1 \%)$ & $04(28.5 \%)$ & $09(64.2 \%)$ \\
ST1 & Crossed & Target-like & $11(78.5 \%)$ & $02(14.2 \%)$ & $01(7.1 \%)$ \\
GT1 & Printed & Target-like & $10(71.4 \%)$ & $0(0 \%)$ & $04(28.5 \%)$ \\
BPT2 & Shared & Target-like & $10(71.4 \%)$ & $02(14.2 \%)$ & $02(14.2 \%)$ \\
ST2 & Adopted & Target-like & $08(57.1 \%)$ & $0(0 \%)$ & $06(42.8 \%)$ \\
BPT1 & Brushed & Target-like & $08(57.1 \%)$ & $01(7.1 \%)$ & $05(35.7 \%)$ \\
ET2 & Sounded & Target-like & $0(0 \%)$ & $03(21.4 \%)$ & $11(78.5 \%)$ \\
GT1 & Clapped & Target-like & $07(50 \%)$ & $01(7.1 \%)$ & $06(42.8 \%)$ \\
ST1 & Joined & Target-like & $11(78.5 \%)$ & $0(0 \%)$ & $03(21.4 \%)$ \\
ET1 & Failed & Target-like & $05(35.7 \%)$ & $0(0 \%)$ & $09(64.2 \%)$ \\
ST1 & Reminded & Target-like & $06(42.8 \%)$ & $02(14.2 \%)$ & $06(42.8 \%)$ \\
ET1 & Jumped & Target-like & $05(35.7 \%)$ & $03(21.4 \%)$ & $06(42.8 \%)$ \\
ET2 & Called & Target-like & $06(42.8 \%)$ & $04(28.5 \%)$ & $04(28.5 \%)$ \\
GT2 & Dressed & Target-like & $06(42.8 \%)$ & $03(21.4 \%)$ & $05(35.7 \%)$ \\
BPT2 & Counted & Target-like & $10(71.4 \%)$ & $01(7.1 \%)$ & $03(21.4 \%)$ \\
Total & & & $\mathbf{1 2 7}(\mathbf{5 0 . 4 \% )}$ & $\mathbf{3 7 ( 1 4 . 6 \% )}$ & $\mathbf{8 8}(\mathbf{3 4 . 9 \% )}$ \\
BPT1 & Rented & Coda change & $08(57.1 \%)$ & $01(7.1 \%)$ & $05(35.7 \%)$ \\
GT2 & Planned & Coda change & $02(14.2 \%)$ & $0(0 \%)$ & $12(85.7 \%)$ \\
GT2 & Added & Coda change & $04(28.5 \%)$ & $01(7.1 \%)$ & $09(64.2 \%)$ \\
BPT1 & Changed & Stem & $04(28.5 \%)$ & $10(71.4 \%)$ & $0(0 \%)$ \\
ST2 & Tried & Epenthesis & $11(78.5 \%)$ & $01(7.1 \%)$ & $02(14.2 \%)$ \\
ST2 & Worked & Epenthesis & $04(28.5 \%)$ & $0(0 \%)$ & $10(71.4 \%)$ \\
Total & & & $\mathbf{3 3 ( 3 9 . 2 \% )}$ & $\mathbf{1 3}(\mathbf{1 5 . 4 \% )}$ & $\mathbf{3 8 ( 4 5 . 2 \% )}$ \\
\hline & & & & &
\end{tabular}

$\mathrm{N}=14$ for each verb and 336 for the total

Out of 24 verbs in each test, four verbs had intelligibility rates above $70 \%$ in the first intelligibility test, and seven verbs had this intelligibility rate in the second test. Among these verbs that were highly intelligible, we highlight: 'visited,' 'played,' and 'kissed' target-like produced by BPT2; 'needed' with coda change, replacing /d/ by the flap after the vowel /i/, by BPT1; 'waited,' target-like produced by GT2, 'watched' produced 
by ST1, and 'looked' by ST2, both epenthesized in the first test; whereas verbs 'asked,' 'shared,' and 'counted,' target-like produced by BPT2; 'crossed' and 'joined' target-like produced by ST1; 'printed,' target-like produced by GT1; and 'tried,' epenthesized by ST2 in the second intelligibility test.

Furthermore, the results of the present study suggest that, as occurred with Brazilian listeners (group 2) in Riella's (2013) and in Delatorre, Silveira and Gonçalves' (2017) studies, there seems to be a tendency for the -ed verbs produced by BP and Spanish speakers to be more easily understood and orthographically transcribed by Brazilian listeners than the $-e d$ verbs produced by native speakers of German and English ${ }^{13}$. As discussed by Bent and Bradlow (2003), Jułkowska and Cebrian (2015), Munro, Derwing and Morton (2006) and Roxas (2018), this is likely due to language similarity between listeners' and speakers' L1.

In addition, the higher intelligibility of verbs such as 'visited,' 'waited,' 'needed,' 'counted,' and 'printed', which were produced target-like with the addition of an epenthetic vowel, and 'watched,' 'looked,' and 'tried' produced with an unexpected epenthetic vowel may indicate that it was easier for Brazilian listeners to understand and transcribe verbs that tend to follow the epenthesized production, which is typical of BP and Spanish speakers of English (ALVES, 2004; CABALLERO; ROSADO, 2018; DAVILA, 2018; DELATORRE, 2006; DELATORRE; BAPTISTA, 2014; FERNANDES, 2009; FRESE, 2006; GOMES, 2009; MARIANO, 2009; PEREIRA, 1994). Moreover, as suggested by Munro and Derwing (1995), the recognition of words that follow a prototype tends to be easier, which, in this case, is produced by speakers of Romance languages as BP and Spanish. Verbs 'kissed' and 'played,' 'asked,' 'shared,' 'crossed,' and 'joined' had high intelligibility rates possibly due to learners' frequent contact with these verbs - sometimes inserted in chunks - speakers' and listeners' L1 similarities, or listeners' linguistic background.

On the other hand, as occurred in Delatorre, Silveira and Gonçalves (2017) and displayed in Tables 3 and 4, the number of verbs with low intelligibility rate (lower than $21.4 \%$ ) was higher than the number of verbs with high intelligibility (higher than $71 \%$ ) in both intelligibility tests. For instance, the low intelligibility rates of verbs 'trained,' target-like produced by ET2; 'judged,' target-like produced by ET1; 'spelled,' target-like produced by GT2; 'painted,' target-like produced by ET2; 'voted,' target-like produced by ST2; 'saved,' target-like produced by ST1; 'guided,' target-like produced by GT1;

\footnotetext{
${ }^{13}$ See Hypothesis three in Delatorre (2017) to check intelligibility of verbs produced by speakers of these four L1s for Brazilian learners of English as listeners.
} 
'washed,' target-like produced by GT2; and 'screamed,' epenthesized by ST1; 'sounded' and 'danced,' both target-like produced by ET2; 'proved,' target-like produced by GT1; and 'planned,' produced with coda change in which the final /d/ was replaced by [t] by GT2. Altogether, this suggests that Brazilian listeners had difficulties in listening and transcribing verbs with the three types of target-like pronunciation, as well as produced with epenthesis or with coda change by speakers of English from different L1 backgrounds, but more frequently by speakers of Germanic languages (English or German).

As demonstrated in Table 4, the verbs 'sounded' and 'danced,' produced by ET2, had few instances of intelligible and other verb form transcriptions, and more instances of breakdown transcriptions, possibly because listeners could not identify the past marker for this verb in ET2's speech and/or were not used to this speaker's accent, speech rate, and articulation. Moreover, the verb 'planned,' produced by GT2, had coda change replacing final /d/ in the simple past tense by [t], a common process in German as an L1 (ANTOSEN, 2007), which may be used in English as an L2 (YAVAS, 1994). Possibly, Brazilian listeners were not familiar with this type of pronunciation due to little experience with English spoken by Germans.

Overall, according to the previous discussion, Brazilian listeners had difficulty in understanding and orthographically transcribing the target verbs in both tests, suggesting that the recognition of verbs ending in -ed remained similar with slight changes in intelligibility and other verb forms (see Table 1) rates despite the four-month interval between the tests.

The difficulties in transcribing the verbs may be related to listeners' lack of familiarity with speakers' pronunciation, speech rate, some lexical items, articulation and/or accent (ALAMEEN; LEVIS, 2015; BABBONI; QUAST, 2020; BECKER, 2013; BRADLOW; PISONI, 1999, CRUZ, 2004; FERNANDES, 2009; KENNEDY; TROFIMOVICH, 2008; LEVIS, 2015; JUłKOWSKA; CEBRIAN, 2015; MUNRO; DERWING, 1995, 2015; OLIVEIRA, 2014; ROSA, 2020; ROXAS, 2018). Speakers' L1 might have influenced the intelligibility rates, as suggested by Bent and Bradlow (2003), Jułkowska and Cebrian (2015), and Munro, Derwing and Morton (2006). According to Derwing and Munro (1997), listeners' lack of familiarity with different accents may cause problems in judging and understanding L2 pronunciation and speech, as well as on the establishment of speech patterns to identify speakers' voice and speech, which, according 
to Munro and Derwing (1995), may affect listeners' processing, requiring them more time to understand and transcribe utterances, thus causing breakdowns in communication.

\section{CONCLUSION}

Overall results indicated that Brazilians: (a) presented some difficulty in transcribing the verbs, as demonstrated by low intelligibility rates and high rates of breakdowns in both tests; (b) achieved a slight improvement in the intelligibility percentages from the first to the second test; and (c) decreased the rates of other verb forms from the first to the second test. Moreover, results also show that the intelligibility rates of verbs ending in -ed in this study were lower than the intelligibility rates in other studies, which was probably due to: (a) speakers' L1, since Brazilian learners of English had more difficulty in recognizing and orthographically transcribing verbs produced by German and English L1 speakers than by BP and Spanish speakers; (b) listeners' lack of familiarity with speakers' speech characteristics; and (c) test conditions (e.g., noisy room, reading task with sentences without past tense markers). Different trends were observed in the two intelligibility tests: Higher intelligibility rates for non-target-like productions than for target-like productions in the first test, but not in the second one. These results might be related to listeners' familiarity with the test format or even with their improved proficiency level after four additional months of classroom-based instruction.

The results of the present study indicate the complexity of L2 pronunciation development and pronunciation assessment through intelligibility measures. Before concluding, it is important to highlight some limitations of the present study. First, test conditions in which the speech is recorded and/or presented to the listeners (e.g., reading, free speech, quiet or noisy room), as suggested by Alameen and Levis (2015), Babboni and Quast (2020), Munro and Derwing (2015), and Trofimovich, Kennedy and Foote (2015), might have affected the results since the intelligibility tests were conducted in listeners' classrooms, which was not an ideal lab condition due to outside noise. Another possible effect was the test itself, which was based on listening to sentences written in the simple past without past markers that could aid the listeners, making the test more difficult despite the fact that speakers were instructed to read the sentences in which the verbs were inserted as naturally as possible. 


\section{REFERENCES}

ALAMEEN, Ghinwa; LEVIS, John M.. Connected speech. In: REED, Marnie; LEVIS, John M. (org.). The Handbook of English Pronunciation. West Sussex: Wiley Blackwell, 2015. p. 159-174.

ALLAN, Dave. Oxford Placement Test 1. Oxford: Oxford University Press, 2004.

ALVES, Ubiratã K. O papel da instrução explícita na aquisição fonológica do inglês como L2: evidências fornecidas pela teoria da otimidade. 2004. 336 f. Dissertação (Mestrado em Letras) - Programa Pós-Graduação em Letras, Universidade Católica de Pelotas, Pelotas, 2004.

ANTONSEN, Elmer H. Elements of German: phonology and morphology. Tuscaloosa: University Alabama Press, 2007.

BABBONI, Carlos A.; QUAST, Karin. Pronunciation and Aeronautical English: Brazilians' difficulties and possible routes to intelligibility. The Especialist, [S.l.], v. 41, n. 4, p. 1-28, out. 2020. Disponível em: https://doi.org/10.23925/2318-7115.2020v41i4a3. Acesso em: 28 maio 2021.

BECKER, Marcia R. Inteligibilidade da língua inglesa sob o paradigma de língua franca: percepção de discursos de falantes de diferentes L1s por brasileiros. 2013. 260 f. Tese (Doutorado em Letras) - Programa de Pós-Graduação em Letras, Universidade Federal do Paraná, Curitiba, 2013. Disponível em: https://hdl.handle.net/1884/32270. Acesso em: 28 maio 2021.

BENT, Tessa; BRADLOW, Ann R. The interlanguage speech intelligibility benefit. Journal of The Acoustical Society of America, [S.l.], v. 114, n. 3, p. 1600-1610, set. 2003. Disponível em: https://doi.org/10.1121/1.1603234. Acesso em: 28 maio 2021.

BRADLOW, Ann R.; PISONI, David B. Recognition of spoken words by native and nonnative listeners: talker-, listener-, and item-related factors. Journal of The Acoustical Society of America, [S.l.], v. 106, n. 4, p. 2074-2085, out. 1999. Disponível em: https:// doi.org/10.1121/1.427952. Acesso em: 28 maio 2021.

CABALLERO, David R.; ROSADO, Nayibe. Neurolinguistic programming and regular verbs past tense pronunciation teaching. English Language Teaching, [S.l.], v. 11, n. 11, p. 1-18, out. 2018. Disponível em: http://doi.org/10.5539/elt.v11n11p1. Acesso em: 28 maio 2021. 
CATFORD, John C. Intelligibility. English Language Teaching Journal, [S.l.], v. V, n. 1, p. 7-15, out. 1950. Disponível em: https://doi.org/10.1093/elt/V.1.7. Acesso em: 28 maio 2021.

CELCE-MURCIA, Marianne; BRINTON, Donna M.; GOODWIN, Janet M. Teaching Pronunciation: a course book and reference guide. 2. ed. Cambridge: Cambridge University Press, 2010.

CRUZ, Neide F. C. Pronunciation intelligibility in spontaneous speech of Brazilian learners English. 2004. 260 f. Tese (Doutorado em Letras) - Programa de Pós-Graduação em Letras/Inglês e Literatura Correspondente, Universidade Federal de Santa Catarina, Florianópolis, 2004.

CRYSTAL, David. English as a Global Language. 2. ed. Cambridge: Cambridge University Press, 2003.

DAVILA, Angel M. Pronunciation acquisition of the inflectional morpheme-ed in English by Nicaraguan Spanish speakers. Open Science Journal, [S.l.], v. 3, n. 1, p. 1-22, fev. 2018. Disponível em: https://doi.org/10.23954/osj.v3i1.1516. Acesso em: 28 maio 2021.

DELATORRE, Fernanda. Brazilian EFL learners' production of vowel epenthesis in words ending in -ed. 2006. 214 f. Dissertação (Mestrado em Letras) - Programa de Pós-Graduação em Letras/Inglês e Literatura Correspondente, Universidade Federal de Santa Catarina, Florianópolis, 2006. Disponível em: https://repositorio.ufsc.br/ handle/123456789/88753. Acesso em: 28 maio 2021.

DELATORRE, Fernanda. O efeito do treinamento perceptual na produção do -ed por brasileiros falantes de inglês como LE. In: OLIVEIRA, S. (org.). Anais do XVIII Seminário do Centro de Estudos Linguísticos e Literários do Paraná. Ponta Grossa: Universidade Estadual de Ponta Grossa, 2009. p. 22-22.

DELATORRE, Fernanda. Production and phonological representation of simple past tense -ed by two Brazilian EFL speakers. In: RAUBER, Andréia S.; WATKINS, Michael A.; SILVEIRA, Rosane; KOERICH, Denise. (org.). The acquisition of second language speech: Studies in honor of professor Barbara O. Baptista. Florianópolis: Insular, 2010. p. 195-220.

DELATORRE, Fernanda. Intelligibility of English verbs ending in -ed for Brazilian learners of English as listeners. 2017. 312 f. Tese (Doutorado em Inglês) - Programa de Pós-Graduação em Inglês: Estudos Linguísticos e Literários, Universidade Federal de Santa Catarina, Florianópolis, 2017. Disponível em: https://repositorio.ufsc.br/ handle/123456789/187266. Acesso em: 28 maio 2021. 
DELATORRE, Fernanda; BAPTISTA, Barbara O. The effect of long-term instruction on a Brazilian learner's pronunciation of regular verbs ending in -ed. Revista X, Curitiba, v. 1, n. 1, p. 58-79, ago. 2014. Disponível em: http://dx.doi.org/10.5380/rvx.v1i0.2014.34535. Acesso em: 28 maio 2021.

DELATORRE, Fernanda; GONÇALVES, Alison R.; SILVEIRA, Rosane. Production of English verbs ending in -ed by speakers from different L1 backgrounds. Entrepalavras, Fortaleza,v.10,n.1,p. 141-165, abr. 2020.Disponível em:http://dx.doi.org/10.22168/22376321-11756. Acesso em: 28 maio 2021.

DELATORRE, Fernanda; SILVEIRA, Rosane; GONÇALVES, Alison R. The intelligibility of English verbs in the simple past tense. Veredas: Revista de Estudos Linguísticos, Juiz de Fora, v. 21, n. 2, p. 57-77, fev. 2017. Disponível em: https://doi.org/10.34019/19822243.2017.v21.27975. Acesso em: 28 maio 2021.

DERWING, Tracey M.; MUNRO, Murray J. Accent, intelligibility, and comprehensibility: Evidence from four L1s. Studies in Second Language Acquisition, [S.l.], v. 19, n. 1, p. 1-16, mar. 1997. Disponível em: https://doi.org/10.1017/S0272263197001010. Acesso em: 28 maio 2021.

DERWING, Tracey M.; MUNRO, Murray J. Accent and intelligibility: Cracking the conundrum. The BELTA Bulletin, [S.l.], v. 6, Winter, p. 4-9, 2015. Disponível em: https://www.beltabelgium.com/sites/beltabelgium/files/belta_bulletin_6_winter_2015. pdf. Acesso em: 05 de abril de 2021.

FERNANDES, Renata K. M. Inteligibilidade e inglês como língua internacional: um estudo de caso da pronúncia de palavras em -ed produzidas por falantes brasileiros. 2009. 113 f. Dissertação (Mestrado em Estudos Ingleses e Americanos) - Curso de Mestrado em Estudos Ingleses e Americanos, Universidade de Lisboa, Lisboa, 2009. Disponível em: https://repositorio.ul.pt/bitstream/10451/386/1/20080_ulf1064851_tm.pdf. Acesso em: 28 maio 2021.

FRESE, Rudinei A. The relationship between perception and production of words ending in -ed by Brazilian EFL learners. 2006. 141 f. Dissertação (Mestrado em Letras) Programa de Pós-Graduação em Letras/Inglês e Literatura Correspondente, Universidade Federal de Santa Catarina, Florianópolis, 2006. Disponível em: http://repositorio.ufsc.br/ xmlui/handle/123456789/88576. Acesso em: 28 maio 2021.

GOMES, Maria Lúcia C. A produção de palavras do inglês com o morfema ed por falantes brasileiros: uma visão dinâmica. 2009. 240 f. Tese (Doutorado em Letras) Curso de Pós-Graduação em Letras, Universidade Federal do Paraná, Curitiba, 2009. Disponível em: https://hdl.handle.net/1884/19779. Acesso em: 28 maio 2021. 
GOMES, Maria Lúcia C.; BAWERMAN-ALBINI, Andressa; ENGELBERT, Ana Paula P F. The perception of vowel epenthesis and word stress in an English as a lingua franca context. Concordia Working Papers in Applied Linguistics, Montreal, v. 5, n. 1, p. 185202, mar. 2014. Disponível em: http://doe.concordia.ca/copal/documents/15_Gomes_ etal_Vol5.pdf. Acesso em: 28 maio 2021.

JUłKOWSKA, Izabela A.; CEBRIAN, Juli. Effects of listener factors and stimulus properties on the intelligibility, comprehensibility and accentedness of L2 speech. Journal of Second Language Pronunciation, [S.L.], v. 1, n. 2, p. 211-237, set. 2015. Disponível em: https://doi.org/10.1075/jslp.1.2.04jul. Acesso em: 28 maio 2021.

KACHRU, Braj. Standards, codification and sociolinguistic realism: The English language in the outer circle. In: QUIRK, Randolph; WIDDOWSON, Henry G. (org.). English in the World: Teaching and learning the language and literatures. Cambridge: Cambridge University Press, 1985. p. 11-30.

KENNEDY, Sara; TROFIMOVICH, Pavel. Intelligibility, comprehensibility, and accentedness of L2 Speech: The role of listener experience and semantic context. Canadian Modern Language Review, Toronto, v. 64, n. 3, p. 459-489, mar. 2008. Disponível em: https://doi.org/10.3138/cmlr.64.3.459. Acesso em: 28 maio 2021.

LEVIS, John M. The Journal of Second Language Pronunciation: an essential step toward a disciplinary identity. Journal of Second Language Pronunciation, [S.l.], v. 1, n. 1, p. 1-10, mar. 2015. Disponível em: https://doi.org/10.1075/jslp.1.1.001edi. Acesso em: 28 maio 2021.

MARIANO, Mariana $\mathrm{H}$. The influence of training and instruction on the production of verbs ending in -ed by Brazilian EFL learners. 2009. 89 f. Dissertação (Mestrado em Letras) - Programa de Pós-Graduação em Letras/Inglês e Literatura Correspondente, Universidade Federal de Santa Catarina, Florianópolis, 2009. Disponível em: http:// repositorio.ufsc.br/xmlui/handle/123456789/93434. Acesso em: 28 maio 2021.

MUNRO, Murray J.; DERWING, Tracey M. Processing time, accent, and comprehensibility in the perception of native and foreign-accented speech. Language and Speech, [S.L.], v. 38, n. 3, p. 289-306, jul. 1995. Disponível em: https://doi. org/10.1177/002383099503800305. Acesso em: 28 maio 2021.

MUNRO, Murray J.; DERWING, Tracey M. Intelligibility in research and practice: teaching priorities. In: REED, Marnie; LEVIS, John M. (org.). The Handbook of English Pronunciation. West Sussex: Wiley Blackwell, 2015. p. 377-396. 
MUNRO, Murray J.; DERWING, Tracey M.; MORTON, Susan L. The mutual intelligibility of L2 speech. Studies in Second Language Acquisition, [S.l.], v. 28, n. 01, p. 111-131, fev. 2006. Disponível em: https://doi.org/10.1017/S0272263106060049. Acesso em: 28 maio 2021.

OLIVEIRA, Gabriela R. N. Inglês como língua franca e inteligibilidade de fala: um estudo com usuários brasileiros. 2014. 132 f. Dissertação (Mestrado em Língua e Cultura) - Programa de Pós-Graduação em Língua e Cultura, Universidade Federal da Bahia, Salvador, 2014. Disponível em: http://repositorio.ufba.br/ri/handle/ri/27840. Acesso em: 28 maio 2021.

PEREIRA, Claudia M. Acquisition of morphological rules by EFL Brazilian students. 1994. 176 f. Dissertação (Mestrado em Letras) - Curso de Programa de Pós-Graduação em Inglês, Universidade Federal de Santa Catarina, Florianópolis, 1994. Disponível em: https://repositorio.ufsc.br/handle/123456789/111357. Acesso em: 28 maio 2021.

RIELLA, Roberta J. Inteligibilidade de palavras terminadas com morfema ed no contexto de inglês como língua franca. 2013. 84 f. Monografia (Especialização) Curso de Especialização no Ensino de Línguas Estrangeiras Modernas, Universidade Tecnológica Federal do Paraná, Curitiba, 2013. Disponível em: http://repositorio.utfpr. edu.br/jspui/handle/1/19003. Acesso em: 28 maio 2021.

ROSA, Eliane N. Uma proposta de ensino de pronúncia da língua inglesa com ênfase nas consciências fonoarticulatória e grafofonológica. In: MAGALHÃES, Cristiane R.; FARIA, Johnwill C.; EGIDO, Alex A. (org.). Anais do XVI Encontro de Formação de Professores de Língua Estrangeira. Inhumas: Universidade Estadual de Goiás, 2020. p. 1-12. Disponível em: https://www.anais.ueg.br/index.php/enfople/index. Acesso em: 28 maio 2021.

ROSSINI, Carolina; FRACARO, Bruna N.; BRAWERMAN-ALBINI, Andressa. A percepção do morfema ed em verbos regulares do inglês no passado: um estudo longitudinal. In: BRAWERMAN-ALBINI, Andressa; BECKER, Marcia R.; GOMES, Maria Lúcia C. (org.). Pesquisa na licenciatura em Letras: caminhos possíveis para o professor de língua estrangeira. 2. ed. Campinas: Pontes, 2018. p. 15-35.

ROSSINI, Carolina; FRACARO, Bruna N.; GOMES, Maria Lúcia C.; BRAWERMANALBINI, Andressa. /t/ /d/ ou /Id/? Um estudo sobre a percepção do morfema -ed dos verbos regulares no passado em inglês por falantes brasileiros. Travessias Interativas, [S.l.], v. 14, n. 1, p. 345-358, maio 2018. Disponível em: https://seer.ufs.br/index.php/ Travessias/article/view/9140/7163. Acesso em: 28 maio 2021. 
ROXAS, Jeff B. Investigating the status of English as a lingua franca in Southeast Asia: Intelligibility and comprehensibility of ASEAN Englishes among Filipino college students. Philippine Journal of Linguistics, [S.l.], v. 49, n. 1, p. 1-25, dez. 2018. Disponível em: https://www.pjl-phil.com/article/2018/49/Jeff-B.-Roxas. Acesso em: 28 maio 2021.

SCHWARTZHAUPT, Bruno M. Testing intelligibility in English: the effects of positive VOT and contextual information in a sentence-transcription task. 2015. 86 f. Dissertação (Mestrado em Letras) - Curso de Programa de Pós-Graduação em Letras, Universidade Federal do Rio Grande do Sul, Porto Alegre, 2015. Disponível em: http://hdl.handle. net/10183/131639. Acesso em: 28 maio 2021.

SEIDLHOFER. Barbara. Understanding English as a Lingua Franca. Oxford: Oxford University Press, 2011.

SILVERIA, Rosane; ALVES, Ubiratã K. Noticing e instrução explícita: aprendizagem fonético-fonológica do morfema -ed. Nonada: Letras em Revista, Porto Alegre, v. 2, n. 13, p. 1-10, out. 2009.

SILVEIRA, Rosane; DELATORRE, Fernanda; REIS, Leonice P.; GONÇALVES, Alison R. Percepção, produção e inteligibilidade do inglês falado por usuários brasileiros. In: TOMITCH, Lêda M. B.; HEBERLE, Viviane M. (org.). Perspectivas atuais de aprendizagem e ensino de línguas. Florianópolis: LLE/CCE/UFSC, 2017. p. 237-283.

SMITH, Larry E.; NELSON, Cecil L. International intelligibility of English: directions and resources. World Englishes, [S.l.], v. 4, n. 3, p. 333-342, nov. 1985. Disponível em: https://doi.org/10.1111/j.1467-971X.1985.tb00423.x. Acesso em: 28 maio 2021.

TROFIMOVICH, Pavel; KENNEDY, Sara; FOOTE, Jennifer A. Variables affecting L2 pronunciation development. In: REED, Marnie; LEVIS, John M. (org.). The Handbook of English Pronunciation. West Sussex: Wiley Blackwell, 2015. p. 353-373.

YAVAS, Mehmet. Final stop devoicing in interlanguage. In: YAVAS, Mehmet (org.). First and second language phonology. San Diego: Singular Publishing Group Inc, 1994. p. 267-282.

YAVAS, Mehmet. Applied English Phonology. 2nd. ed. West Sussex: Wiley Blackwell, 2011. 


\section{APPENDIX A}

\section{Sentences used in Delatorre (2017) and in the first intelligibility test}

01 BPT2: She bought a new car.

02 ST2: They voted in the elections.

03 ET2: Students trained for the test.

04 GT2: Mary washed her dress.

05 ST1: They came by bus.

06 BPT1: The stadium cheered him.

07 GT1: Tom guided visitors.

08 ET1: Bob stopped smoking.

09 BPT2: She played piano.

10 GT2: He drove for 18 hours.

11 ST1: They watched a movie.

12 ET2: Helen painted her bedroom.

13 GT1: The audience laughed out loud.

14 BPT1: He needed a job.

15 ET1: She made a cake.

16 ST1: The pilot saved all passengers.

17 BPT2: I visited my family.

18 GT1: They took a trip.

19 ST2: She looked for a new job.

20 ET1: They judged a robber.

21 BPT1: They skipped some exercises.

22 ST1: Models avoided eating.

23 ET2: He wrote a letter. 
24 GT1: The driver caused an accident.

25 ST2: The family had breakfast together.

26 BPT2: Suzy kissed her father.

27 GT2: The teacher spelled his name.

28 ET1: He recorded a video.

29. BPT1: Kids slept for 10 hours.

30 ST2: Children screamed a lot.

31 ET2: He missed some classes.

32. GT2: They waited for the train

\section{APPENDIX B}

\section{Sentences used in the second intelligibility test}

01 GT1: Jack proved his innocence.

02 ET1: The family attended a concert.

03 BPT2: She asked my name.

04 ST1: Lisa drew a bird.

05 ET2: Students danced all night.

06 ST2: Susan tried her best.

07 GT2: Kids saw a black dog.

08 BPT1: They rented a car.

09 ST1: They crossed a famous street.

10 GT1: John printed his paper.

11 BPT2: Boys shared a house.

12 ET2: They woke up late on Sunday.

13 ST2: They adopted a child. 
14 BPT1: George brushed his teeth.

15 ET1: Anna taught English for years.

16 GT2: Ann and Bob planned a trip.

17 BPT2: They drank a lot.

18 ET2: His speech sounded fine to us.

19 GT1: The man clapped his hands

20 ST1: Students joined a group.

21 BPT1: They fought at school.

22 ST2: They worked hard.

23 GT2: The teacher added a new student.

24: ET1: He failed in the Math test.

25 ST1: This reminded me of his songs.

26 GT1: Journalists gave us bad news.

27 ET1: The chief jumped a wall.

28 BPT1: He changed his mind.

29 ST2: Paul sang for three hours.

30 BPT2: Police counted one million people.

31 ET2: James called his parents.

32 GT2: Helen dressed well 